\title{
Evaluation of the Perceptions of Safety of Surgical Practice at a Tertiary Academic Trauma Hospital in Havana, Cuba
}

\author{
Evelyn M Serrano ${ }^{1}$, George Molina ${ }^{2}$, Geoffrey A Anderson ${ }^{3}$, Sara J Singer ${ }^{4}$, William R Berry ${ }^{5}$, Alex B Haynes ${ }^{6}$, \\ Martha E Larrea Fabra ${ }^{7}$, Marc A de Moya ${ }^{8}$
}

\begin{abstract}
Aim: The aim of this study was to demonstrate the feasibility of measuring the perceptions of safety of surgical practice in a tertiary hospital in Havana, Cuba.

Materials and methods: A validated survey used to measure the perceptions of safety of surgical practice among operating room (OR) personnel was translated into Spanish. The survey was administered to all OR personnel who worked at the General Calixto García Hospital between June 15, 2015, and October 30, 2017. The survey consisted of two demographic questions and 16 items that respondents could answer using a seven-point Likert scale. Responses were dichotomized and evaluated between surgeons and trainees and between participants with $\leq 5$ years and $\geq 6$ years of experience.

Results: There were 200 respondents (response rate of 46.5\%, 200/430), which included 55 (27\%) surgeons, 116 (58\%) trainees, 10 (5\%) anesthesiologists, and 19 (9.5\%) nurses. The majority of respondents reported having $\leq 5$ years of experience $(71.4 \%, n=142)$. Surgeons and participants with $\geq 6$ years of experience more often had a significantly more favorable perception of surgical safety than trainees and participants with $\leq 5$ years of experience, respectively.

Conclusion: The perceptions of safety of surgical practice were successfully measured at a tertiary hospital in Havana, Cuba. The perception of surgical safety differed according to professional role and years of experience.

Clinical significance: Making surgery safer includes fostering a favorable culture of surgical safety in the OR so that all personnel feel empowered to speak up and act on behalf of patient's safety.

Keywords: Cuba, Latin America, Patient safety, Perceptions of safety of surgical practice, Survey study.
\end{abstract}

\section{Resumen español}

Objetivo: El objetivo de este estudio fue demostrar la viabilidad de medir las percepciones de seguridad de la práctica quirúrgica en un hospital terciario en La Habana, Cuba.

Material y métodos: Se tradujo al español una encuesta validada para medir las percepciones de seguridad de la práctica quirúrgica entre el personal del quirófano. La encuesta se administró a todo el personal de quirófano en el Hospital General Calixto García entre el 15 de junio de 2015 y el 30 de octubre de 2017. La encuesta consistió en dos preguntas demográficas y 16 artículos que los encuestados pudieron responder utilizando una escala Likert de 7 puntos. Las respuestas fueron dicotomizadas y evaluadas entre cirujanos y profesionales de la salud en formación y entre participantes con $\leq 5$ años $y \geq 6$ años de experiencia.

Resultados: Hubieron 200 encuestados (tasa de respuesta del 46.5\%, 200/430), que incluyeron 55 (27\%) cirujanos, 116 (58\%) profesionales de la salud en formación, 10 (5\%) anestesiólogos y 19 (9.5\%) enfermeras. La mayoría de los encuestados tenían $\leq 5$ años de experiencia (71.4\%, $n=142$ ). Los cirujanos y participantes con $\geq 6$ años de experiencia más frecuentemente tenían una percepción significativamente más favorable de la seguridad quirúrgica que los profesionales de la salud en formación y participantes con $\leq 5$ años de experiencia, respectivamente.

Conclusiones: Las percepciones de seguridad de la práctica quirúrgica se midieron con éxito en un hospital terciario en La Habana, Cuba. La percepción de seguridad quirúrgica fue diferente según el rol profesional y los años de experiencia.

Importancia clínica: Para hacer la cirugía más segura, es esencial fomentar una cultura favorable a la seguridad quirúrgica en el quirófano para que todo el personal se sienta capacitado para promover la seguridad del paciente.

Palabras clave: Seguridad del paciente, Percepciones de seguridad de la práctica quirúrgica, América Latina, Cuba, Estudio de encuesta. Panamerican Journal of Trauma, Critical Care \& Emergency Surgery (2020): 10.5005/jp-journals-10030-1289

\section{INTRODUCTION}

As the availability of surgical care expands throughout the world, the gap in mortality and morbidity between high-income and lowand middle-income countries (LMICs) becomes an important issue to address. Between 2004 and 2012, the total annual global surgical volume increased from 226.4 million to 312.9 million operations, an estimated $38.2 \%$ increase. ${ }^{1}$ Despite these findings showing higher surgical volume globally, postoperative morbidity and mortality have been shown to be significantly higher in LMICs compared

\footnotetext{
1,7 Department of Surgery, Universidad de Ciencias Médicas de La Habana, Facultad de Ciencias Médicas "General Calixto García", Avenida Universidad y J. Vedado, Plaza, La Habana, CP, Cuba

${ }^{2}$ Ariadne Labs at Brigham and Women's Hospital and the Harvard TH Chan School of Public Health, Boston, Massachusetts, USA

${ }^{3}$ Department of Surgery, Massachusetts General Hospital, Boston, Massachusetts, USA

${ }^{4}$ Massachusetts General Hospital, Mongan Institute for Health Policy, Boston, Massachusetts, USA
} 
to high-income countries. ${ }^{2-4}$ Ongoing work to improve access to surgical care throughout the world should also incorporate the need to improve the safety of surgical care in limited-resource settings.

Understanding the perceptions of safety of surgical practice in the operating room is an essential component of making surgery safer. The culture of safety can be evaluated by measuring the perception of safety of professionals who work in a particular environment. ${ }^{5}$ Singer et al. have previously developed and validated a survey to measure the perceptions of safety of surgical practice specifically in an operating room. ${ }^{6}$ This survey has been used to measure the perceptions of surgical safety in operating rooms located in the state of South Carolina and in operating rooms in ambulatory surgery centers in the United States., ${ }^{7,8}$ Use of this validated survey has demonstrated that hospitals with an unfavorable perception of surgical safety had worse postoperative mortality compared to hospitals that had a favorable perception of surgical safety. ${ }^{9}$ Furthermore, measuring the perceptions of safety of surgical practice can serve as a needs-based assessment that can inform subsequent quality improvement initiatives that aim to improve the safety of surgical care.

Measuring, interpreting, and learning from the perceptions of safety of surgical practice occurs infrequently, if at all, in hospitals located in LMICs. We sought to measure the perceptions of safety of surgical practice at the General Calixto García University, Hospital of Havana, Cuba, in order to advance this line of research and to improve the quality of surgical care.

\section{Materials and Methods}

\section{Validated Survey Instrument}

A validated survey ${ }^{6}$ used to measure the perceptions of safety of surgical practice among operating room personnel was translated into Spanish by a research assistant (E. F.), a native Spanish speaker, and then reverse translated into English by G. M., a bilingual English and Spanish speaker. Discrepancies between the original version and the reverse translated version were addressed in the translated Spanish version, which was then reviewed and edited by E. M. S. and M. E. L. F, a trainee in surgery and a trauma surgeon, respectively, at the General Calixto García Hospital in Havana, Cuba. The original English version has been previously published. ${ }^{7}$ See the translated Spanish version in Figure 1. The survey consisted of three sections. The first section asked about demographic information, including professional role and number of years of experience in that position. The second section consisted of 16 statements that survey participants were instructed to respond to with their level of agreement or disagreement using a seven-point Likert-scale, which ranged from "Strongly Disagree" to "Strongly Agree" (see English version of survey in Fig. 1). The third section allowed participants to write in comments. This study only includes the responses to sections 1 and 2 .

\section{Study Setting}

The General Calixto García Hospital was founded in 1896 and it is the oldest teaching hospital in Cuba. It serves the population from three municipalities (Habana Vieja, Centro Habana, and Alamar) and two provinces (Mayabeque and Artemis). The hospital is equipped with 57 surgical beds and 17 operating rooms, three of which are used for urgent operations. As a teaching hospital, it is home to a general surgery residency that consists of 105 modules that are completed through the course of 5 years. Surgical trainees receive
${ }^{5,6}$ Ariadne Labs, Boston, Massachusetts, USA

${ }^{8}$ Department of Surgery, Medical College of Wisconsin, Milwaukee, Wisconsin, USA

Corresponding Author: Marc A de Moya, Department of Surgery, Medical College of Wisconsin, Milwaukee, Wisconsin, USA. Phone: +1 (414) 955-1734, e-mail: mdemoya@mcw.edu

How to cite this article: Serrano EM, Molina G, Anderson GA, et al. Evaluation of the Perceptions of Safety of Surgical Practice at a Tertiary Academic Trauma Hospital in Havana, Cuba. Panam J Trauma Crit Care Emerg Surg 2020;9(2):114-119.

Source of support: Nil

Conflict of interest: None

training in general surgery, trauma, gynecologic surgery, breast surgery, thoracic surgery, pediatric surgery, minimally invasive surgery, and surgical oncology.

\section{Study Participants}

All 430 healthcare professionals who worked in the operating room at General Calixto García Hospital between June 15, 2015, and October 30, 2017, were eligible to voluntarily participate in this study, and these included surgeons, residents/trainees/others (who will be referred to as trainees), anesthesiologists, and surgical nurses. The survey as administered during this time period and a total of 250 surveys were completed and 50 incomplete surveys were excluded from the final analysis.

\section{Statistical Analysis}

Responses to the 16 statements in section 2 were dichotomized into Agree and Disagree. Of the 16 statements, 12 statements were affirmative statements and a perception of safety of surgical practice would coincide with responses of "Agree" or "Strongly Agree" to these statements. For example, for statement 1, "Everyone participates in efforts to improve patient safety," a perception of surgical safety would coincide with participants reporting that they "Agree" or "Strongly Agree" that this statement reflects the operating room environment that they work in at the General Calixto García Hospital. For these 12 affirmative statements, "Agree" and "Strongly Agree" were dichotomized to Agree and the other responses ranging from "Strongly Disagree" to "Somewhat Agree" were dichotomized to Disagree. The remaining four statements (statements 3, 6, 11, and 14) were negative statements and a perception of safety of surgical practice would coincide with responses of "Strongly Disagree" and "Disagree," and these were dichotomized to Disagree. Conversely, the remaining responses ranging from "Somewhat Disagree" to "Strongly Agree" were dichotomized to Agree.

The statistical analysis evaluated differences in the perception of surgical safety between professional roles and between participants with different years of experience. Due to low sample size of anesthesiologists and surgical nurses, the statistical analysis according to the professional role was limited to surgeons and trainees. Due to low sample sizes, participants who responded that their years of experience was $<1$ year and $1-5$ years were grouped together. Similarly, participants with $6-10$ years and $>10$ years of experience were grouped together. Analyses were performed using chi-square tests to evaluate if there were differences in the perception of surgical safety for each of the 16 statements between surgeons and trainees and between participants with $\leq 5$ years of experience and $\geq 6$ years of experience. 


\section{Encuesta Sobre la Cultura de Seguridad en el Quirófano}

Este proyecto de investigación consiste en responder la "Encuesta Sobre la Cultura de Seguridad en el Quirófano". Su participación es opcional y voluntaria. Todas las respuestas serán confidenciales y le solicitamos atentamente que no proporcione información adicional a la que aquí se solicita. Este cuestionario se refiere a los quirófanos en los que trabaja más frecuentemente y los equipos médicos con los que colabora en ellos. En varias preguntas se hará referencia a su equipo, hágase referencia entonces todas las personas con las que colabora en el quirófano durante procedimientos quirúrgicos. Por favor responda de acuerdo al promedio de sus experiencias. Este cuestionario no debe tomar más de 5 minutos, lo invitamos a responder tantas preguntas como le sea posible.

Si tiene alguna duda o comentario con respecto a este instrumento, por favor no dude en preguntar a los Drs. DeMoya, Molina o Fuentes. Gracias por su participación.

\begin{tabular}{|lll}
\hline A. ¿Cuál es su puesto actualmente? & \\
\hline${ }^{01} \mathrm{O}$ Cirujano & ${ }^{04} \mathrm{O}$ Enfermera quirúrgica & ${ }^{07} \mathrm{O}$ Perfusionista \\
${ }^{02} \mathrm{O}$ Anestesiólogo & ${ }^{05} \mathrm{O}$ Asistente médico & ${ }^{08} \mathrm{O}$ Interno/Residente/Residente de subespecialidad \\
${ }^{03} \mathrm{O}$ Anestesiólogo no médico & ${ }^{06} \mathrm{O}$ Técnico & ${ }^{99} \mathrm{O}$ Otro:
\end{tabular}

B. ¿Cuántos años ha permanecido en este puesto (en este $u$ otro hospital)?
${ }^{01} \mathrm{O}<1$ año $\quad{ }^{02} \mathrm{O}$ 1-5 años $\quad{ }^{03} \bigcirc 6-10$ años ${ }^{04} \mathrm{O}>10$ años

Por favor indique qué tanto está de acuerdo o desacuerdo con las siguientes afirmaciones:

En los quirófanos donde trabajo...

1. Todos se esfuerzan por mejorar la seguridad del paciente

$\begin{array}{lllllll}\begin{array}{c}\text { Totalemente } \\ \text { en } \\ \text { desacuerdo }\end{array} & \begin{array}{c}\text { En } \\ \text { desacuerdo }\end{array} & \begin{array}{c}\text { Un poco } \\ \text { en } \\ \text { desacuerdo }\end{array} & \begin{array}{c}\text { Ni de acuerdo } \\ \text { ni en } \\ \text { desacuerdo }\end{array} & \begin{array}{c}\text { Un poco de } \\ \text { acuerdo }\end{array} & \begin{array}{c}\text { De } \\ \text { acuerdo }\end{array} & \begin{array}{c}\text { Totalmente de } \\ \text { acuerdo }\end{array} \\ \text { (1) } & \text { (2) } & \text { (3) } & \text { (4) } & \text { (5) } & \text { (6) } & \text { (7) }\end{array}$

2. Los miembros del equipo están abiertos al cambio para mejorar la seguridad del paciente, aún si esto implica que el procedimiento quirúrgico tome más tiempo.

3. La necesidad de iniciar rápidamente un caso después del otro se interpone en la seguridad del paciente.

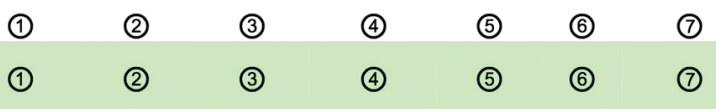

4. Previo a la incisión de piel, los médicos se encuentran presentes y participan activamente en el cuidado del paciente.

5. Comúnmente el caso se discute en equipo (pre o post quirúrgicamente).

6. Es difícil expresar mi opinión cuando percibo problemas en la atención médica hacia el paciente.

7. Los médicos se muestran positivos a lo largo de las operaciones.

8. Todos los miembros del equipo trabajan de manera coordinada.

9. En los casos complejos, durante la discusión previa a iniciar el caso se contemplan posibles complicaciones.

10. Los miembros del equipo comparten información relevante tan pronto esté disponible.

11. Los médicos solo son receptivos a sugerencias si éstas vienen de otro médico.

12. Los miembros del equipo se conducen de manera respetuosa hacia mí.

13. Se me trata como miembro valioso del equipo.

14. Es difícil hablar sobre errores médicos.

15. Todos los miembros del equipo discuten los aspectos relevantes en el manejo postoperatorio del paciente antes de que este sea trasladado fuera del quirófano

$\begin{array}{lllllll}\text { (1) } & \text { (2) } & \text { (3) } & \text { (4) } & \text { () } & \text { () } & 0 \\ \text { (1) } & \text { (2) } & \text { (3) } & \text { (4) } & \text { () } & \text { () } & 0\end{array}$

(1) (2) (3) (4)

(1) (2) (3) (4) (3) (6)

(1) (2) (3) (4) (3) ()

(1) (2) (3) (4) (3) (6) (1)

(1) (2) (3) (4) (3) (6) 8

(1) (2) (3) (4) (3) (6)

(1) (2) (3) (4)

(1) (2) (3) (4)

(1) (2) (3) (4) (3) (6)

(1) (2) (3) (4) (3) (6)

Por favor indique qué tanto está de acuerdo o desacuerdo con la siguiente afirmacion:

\begin{tabular}{lllllll}
\hline \hline 16. Me sentiría seguro(a) como paciente en este hospital. & (1) & (2) & (3) & (4) & (5) (6) \\
\hline \hline
\end{tabular}

Si tiene comentarios adicionales, por favor utilice el espacio proporcionado al reverso de la hoja para desarrollarlos.

Fig. 1: Spanish translation of the survey

Analyses were performed using the Stata (StataCorp) software, version 13.1. A $p$ value of $<0.05$ (double-sided) was used to signify statistical significance. The study was approved by the Institutional Review Boards of Massachusetts General Hospital, Boston, MA, and of the University of Havana, Havana, Cuba.

\section{Results}

The survey response rate was $46.5 \%$ (200 completed surveys out of 430 eligible healthcare providers). The majority of participants were trainees $(58.0 \%, n=116)$, followed by surgeons $(27.5 \%$, $n=55)$, surgical nurses $(9.5 \%, n=19)$, and anesthesiologists $(5 \%$, 
$n=10)$. The highest proportion of participants reported being in their respective role for $1-5$ years $(39.5 \%, n=79$ ) (Table 1). Among trainees, $49.1 \%(n=57)$ reported having $<1$ year of experience in their respective role, and $50.9 \%(n=59)$ reported having $1-5$ years of experience in their respective role. Conversely, $69.1 \%(n=38)$ of the surgeons reported having $\geq 6$ years of experience in their respective role.

Using the Chi-square test to evaluate the differences in perception of surgical safety between surgeons and trainees, there were statistically significant differences between surgeons and trainees in 3 out of the 16 statements (Table 2). Compared to surgeons, trainees were more likely to agree with the following statement: "For complex cases, briefings include planning for potential problems" (statement 9; 69.8\% of agreement among trainees compared to $50.9 \%$ among surgeons, $p$ value $=0.016$ ). Trainees were less likely to agree with the statement (statement 13) that they were "treated as a highly valued member of the team" in comparison to surgeons ( $57.8 \%$ vs $76.4 \%, p$ value 0.018 ). Trainees were also less likely to agree that they "would feel safe being treated here as a patient" (statement $16 ; 47.4 \%$ vs $63.6 \%, p$ value $=0.047$ ).

Table 3 demonstrates the differences in the perception of surgical safety between operating room personnel according to their reported years of experience. Out of the 16 statements, 6 demonstrated statistically significant differences between operating room personnel with $\leq 5$ years of experience and $\geq 6$ years of experience. For all of the six statements that showed a statistically significant difference, operating room staff with $\geq 6$ years of experience reported a more favorable perception of safety of surgical practice when compared to participants who reported $\leq 5$ years of experience. For example, participants with $\geq 6$ years of experience were more likely to disagree that "Pressure to move quickly from case to case gets in the way of patient safety" (statement 3, disagreement among participants with $\geq 6$ years of experience was $54.4 \%$ compared to $37.3 \%$ among participants with $\leq 5$ years of experience, $p$ value $=0.028$ ). Similarly, participants with greater years of experience were more likely to disagree that it was "difficult to speak up when I perceive problems with patient care" (statement $6,61.4 \%$ vs $45.8 \%, p$ value $=0.046$ ). Differences in the four affirmative statements that showed statistically significant differences according to years of experience showed that participants with greater years of experience were more likely to agree that "physicians maintain a positive tone throughout operations" (statement 7, 84.2\% vs. $67.6 \%, p$ value $=0.018$ ); "all team members work together as a well-coordinated team" (statement 8 ,

Table 1: Respondent characteristics

\begin{tabular}{ll}
\hline & $N(\%)$ \\
\hline $\begin{array}{l}\text { Total respondents } \\
\text { Primary professional role }\end{array}$ & $200(100 \%)$ \\
$\quad$ Surgeon & $55(27.5 \%)$ \\
Anesthesiologist & $10(5.0 \%)$ \\
Trainee & $116(58.0 \%)$ \\
Surgical nurse & $19(9.5 \%)$ \\
Years of experience in role* & \\
$<1$ year & $63(31.7 \%)$ \\
$1-5$ years & $79(39.7 \%)$ \\
$6-10$ years & $21(10.6 \%)$ \\
$>10$ years & $36(18.1 \%)$ \\
\hline
\end{tabular}

${ }^{*}$ Missing years of experience in role, $n=1$
$71.9 \%$ vs. $54.2 \%, p$ value $=0.022)$; "I am treated as a highly valued member of the team" (statement 13,75.4\% vs. $57.8 \%, p$ value $=$ $0.020)$; and "I would feel safe being treated here as a patient" (statement $16,73.7 \%$ vs. $45.8 \%, p$ value $<0.001$ ).

\section{Discussion}

The perception of surgical safety can be feasibly measured using a validated, translated into Spanish survey in a tertiary hospital in Havana, Cuba. We found that surgeons were significantly more likely than trainees to report being treated as a highly valued member of the team and feeling safe being treated at their hospital as a patient. Similarly, participants with $\geq 6$ years of experience had a significantly more favorable perception of surgical safety than participants with less experience.

This study's findings underscore that there are differences in how operating room personnel in positions of authority, i.e., physicians, perceive the safety of surgical practice compared to operating room personnel not in positions of authority, i.e., trainees or nonphysicians. Previous studies have shown that surgeons or physicians have a more positive perception of surgical safety than nonsurgeons or nonphysicians, respectively.[6,8] Furthermore, nurses have been found to have the most pessimistic perception of safety when compared to their nonnurse peers. ${ }^{10,11}$ However, nurses have also been identified as the group that had the strongest perception of organizational commitment to safety..$^{12}$ Addressing these differences in the perception of surgical safety is important in creating a psychologically safe environment for all operating room team members.

The findings in this study contribute to the existing literature on the culture of safety in health care that has been reported from hospitals outside the United States. A study performed in Taiwan found that about $48 \%$ of healthcare workers in hospitals held positive attitudes toward teamwork. ${ }^{13}$ Similarly, a study in Lima, Peru, demonstrated that only $51.1 \%$ of healthcare professionals reported a positive perception of safety. ${ }^{14}$ While studies from Greece ${ }^{15}$ and Ghana ${ }^{16}$ have reported that more than $70 \%$ of their healthcare professionals reported a more favorable perception of safety. Regardless of the level of reported safety, this current study and previous studies have demonstrated that the climate of safety and, in particular, that perceptions of surgical safety can be feasibly measured using existing validated surveys.

Initiatives to improve the safety of surgical care require an understanding of the baseline level of safety. Measuring the perception of surgical safety among healthcare providers can serve as a starting point for improvement. Cuba has historically been lauded for providing its citizens with access to universal health care. Through an existing collaboration, leadership at General Calixto García Hospital in Havana, Cuba, expressed an interest in conducting work on improving the safety of care that is provided to their surgical patients. The findings from this study will be used to create initiatives that will target improving teamwork and communication with the goal of improving the safety of surgical practice, and ultimately improving the safety of care that is provided to surgical patients.

\section{LIMITATIONS}

This was the first time that a validated survey to measure the perceptions of safety of surgical practice was used in Cuba. 
Table 2: Differences in perception of surgical safety between surgeons and trainees*

\begin{tabular}{|c|c|c|c|c|c|}
\hline \multirow[b]{2}{*}{ Statement } & \multicolumn{2}{|c|}{ Surgeon } & \multicolumn{2}{|c|}{ Trainee } & \multirow[b]{2}{*}{$p$ value } \\
\hline & Agree (\%) & Disagree (\%) & Agree (\%) & Disagree (\%) & \\
\hline $\begin{array}{l}\text { 1. Everyone participates in efforts to im- } \\
\text { prove patient safety. }\end{array}$ & 41.8 & 58.2 & 49.1 & 50.9 & 0.370 \\
\hline $\begin{array}{l}\text { 2. Team members are open to changes that } \\
\text { improve patient safety even if it means } \\
\text { slowing down. }\end{array}$ & 54.5 & 45.5 & 52.6 & 47.4 & 0.810 \\
\hline $\begin{array}{l}\text { 3. Pressure to move quickly from case to } \\
\text { case gets in the way of patient safety. } \wedge\end{array}$ & 52.7 & 47.3 & 60.3 & 39.7 & 0.346 \\
\hline $\begin{array}{l}\text { 4. Physicians are present and actively } \\
\text { participating in patient care prior to skin } \\
\text { incision. }\end{array}$ & 69.1 & 30.9 & 73.3 & 26.7 & 0.569 \\
\hline $\begin{array}{l}\text { 5. Team discussions (e.g., briefings or } \\
\text { debriefings) are common. }\end{array}$ & 72.7 & 27.3 & 71.6 & 28.5 & 0.873 \\
\hline $\begin{array}{l}\text { 6. It is difficult to speak up when I perceive } \\
\text { problems with patient care. } \wedge\end{array}$ & 40.0 & 60.0 & 52.6 & 47.4 & 0.124 \\
\hline $\begin{array}{l}\text { 7. Physicians maintain a positive tone } \\
\text { throughout the operations. }\end{array}$ & 80.0 & 20.0 & 69.0 & 31.0 & 0.131 \\
\hline $\begin{array}{l}\text { 8. All team members work together as a } \\
\text { well-coordinated team. }\end{array}$ & 67.3 & 32.7 & 57.8 & 42.2 & 0.234 \\
\hline $\begin{array}{l}\text { 9. For complex cases, briefings include } \\
\text { planning for potential problems. }\end{array}$ & 50.9 & 49.1 & 69.8 & 30.2 & 0.016 \\
\hline $\begin{array}{l}\text { 10. Team members share key information } \\
\text { as it becomes available. }\end{array}$ & 83.6 & 16.4 & 75.0 & 25.0 & 0.204 \\
\hline $\begin{array}{l}\text { 11. Physicians are only open to sugges- } \\
\text { tions from other physicians. } \wedge\end{array}$ & 40.0 & 60.0 & 55.2 & 44.8 & 0.064 \\
\hline $\begin{array}{l}\text { 12. Team members communicate with me } \\
\text { in a respectful manner. }\end{array}$ & 70.9 & 29.1 & 62.9 & 37.1 & 0.305 \\
\hline $\begin{array}{l}\text { 13. I am treated as a highly valued member } \\
\text { of the team. }\end{array}$ & 76.4 & 23.6 & 57.8 & 42.2 & 0.018 \\
\hline $\begin{array}{l}\text { 14. It is difficult to discuss medical mis- } \\
\text { takes. }^{\wedge}\end{array}$ & 50.9 & 49.1 & 59.5 & 40.5 & 0.291 \\
\hline $\begin{array}{l}\text { 15. The entire team discusses key concerns } \\
\text { for patient recovery and management } \\
\text { before the patient leaves the room. }\end{array}$ & 60.0 & 40.0 & 56.9 & 43.1 & 0.701 \\
\hline $\begin{array}{l}\text { 16. I would feel safe being treated here as } \\
\text { a patient. }\end{array}$ & 63.6 & 36.4 & 47.4 & 52.6 & 0.047 \\
\hline
\end{tabular}

Certain limitations exist including the inability to include nurses and anesthesiologists in the statistical analysis due to the low number of professionals in these roles that were surveyed. The response rate is moderate but acceptable given the novelty of administering a survey for research purposes at this hospital. Additionally, although the findings are descriptive, reporting survey data on the perception of surgical safety from a LMIC like Cuba is important and expands the existing literature on the subject matter.

\section{Conclusion}

The perceptions of safety of surgical practice among operating room personnel were successfully measured at a tertiary hospital in Havana, Cuba, using a validated, translated survey. This study reports that the perception of surgical safety differed according to professional role and years of experience. More specifically, surgeons had more favorable perceptions about surgical safety than trainees. Additionally, participants with more experience in their respective role also had more favorable perceptions of surgical safety than participants with less experience in their respective roles.

\section{Clinical Significance}

To address these differences, we suggest implementing educational workshops that underscore the importance of teamwork and communication in the operating room. Making surgery safer for patients includes fostering a favorable culture of surgical safety in the operating room so that all operating room personnel feel empowered to speak up and act on behalf of the patient's safety. 
Table 3: Differences in perception of surgical safety between operating room professionals with $\leq 5$ years of experience and $\geq 6$ years of experience*

\begin{tabular}{|c|c|c|c|c|c|}
\hline \multirow[b]{2}{*}{ Statement } & \multicolumn{2}{|c|}{$\leq 5$ years of experience } & \multicolumn{2}{|c|}{$\geq 6$ years of experience } & \multirow[b]{2}{*}{ pvalue } \\
\hline & Agree (\%) & Disagree (\%) & Agree (\%) & Disagree (\%) & \\
\hline 1. Everyone participates in efforts to improve patient safety. & 44.4 & 55.6 & 54.4 & 45.6 & 0.201 \\
\hline $\begin{array}{l}\text { 2. Team members are open to changes that improve patient safety even if } \\
\text { it means slowing down. }\end{array}$ & 49.3 & 50.7 & 63.2 & 36.8 & 0.076 \\
\hline $\begin{array}{l}\text { 3. Pressure to move quickly from case to case gets in the way of patient } \\
\text { safety. }{ }^{\wedge}\end{array}$ & 62.7 & 37.3 & 45.6 & 54.4 & 0.028 \\
\hline $\begin{array}{l}\text { 4. Physicians are present and actively participating in patient care prior to } \\
\text { skin incision. }\end{array}$ & 70.4 & 29.6 & 75.4 & 24.6 & 0.477 \\
\hline 5. Team discussions (e.g., briefings or debriefings) are common. & 70.4 & 29.6 & 75.4 & 24.6 & 0.477 \\
\hline 6. It is difficult to speak up when I perceive problems with patient care. ${ }^{\wedge}$ & 54.2 & 45.8 & 38.6 & 61.4 & 0.046 \\
\hline 7. Physicians maintain a positive tone throughout the operations. & 67.6 & 32.4 & 84.2 & 15.8 & 0.018 \\
\hline 8. All team members work together as a well-coordinated team. & 54.2 & 45.8 & 71.9 & 28.1 & 0.022 \\
\hline 9. For complex cases, briefings include planning for potential problems. & 66.2 & 33.8 & 59.7 & 40.4 & 0.383 \\
\hline 10. Team members share key information as it becomes available. & 73.2 & 26.8 & 82.5 & 17.5 & 0.169 \\
\hline 11. Physicians are only open to suggestions from other physicians. ${ }^{\wedge}$ & 45.8 & 54.2 & 59.7 & 40.4 & 0.077 \\
\hline 12. Team members communicate with me in a respectful manner. & 61.3 & 38.7 & 73.7 & 26.3 & 0.097 \\
\hline 13. I am treated as a highly valued member of the team. & 57.8 & 42.3 & 75.4 & 24.6 & 0.020 \\
\hline 14. It is difficult to discuss medical mistakes. $\wedge$ & 39.4 & 60.6 & 54.4 & 45.6 & 0.055 \\
\hline $\begin{array}{l}\text { 15. The entire team discusses key concerns for patient recovery and man- } \\
\text { agement before the patient leaves the room. }\end{array}$ & 54.9 & 45.1 & 68.4 & 31.6 & 0.080 \\
\hline 16. I would feel safe being treated here as a patient. & 45.8 & 54.2 & 73.7 & 26.3 & $<0.001$ \\
\hline
\end{tabular}

${ }^{*}$ Chi-square tests were performed to evaluate the difference in perception of surgical safety between surgeons and trainees

$\wedge$ Negative statements. Perceptions of safety of surgical practice coincide with disagreeing with the statement

\section{Acknowledgments}

The study was approved by the Institutional Review Boards of Massachusetts General Hospital, Boston, MA, and of the University of Havana, Havana, Cuba.

\section{References}

1. Weiser $T G$, Haynes $A B$, Molina $G$, et al. Size and distribution of the global volume of surgery in 2012. Bull World Health Organ 2016;94(3):201-209F. DOI: 10.2471/BLT.15.159293.

2. GlobalSurg Collaborative. Surgical site infection after gastrointestinal surgery in high-income, middle-income, and low-income countries: a prospective, international, multicentre cohort study. Lancet Infect Dis 2018;18(5):516-525. DOI: 10.1016/S1473-3099(18)30101-4.

3. GlobalSurg Collaborative. Mortality of emergency abdominal surgery in high-, middle- and low-income countries. Br J Surg 2016;103(8):971988. DOI: 10.1002/bjs.10151.

4. Bainbridge D, Martin J, Arango M, et al. Perioperative and anaestheticrelated mortality in developed and developing countries: a systematic review and meta-analysis. Lancet 2012;380(9847):10751081. DOI: 10.1016/S0140-6736(12)60990-8.

5. Sammer CE, Lykens K, Singh KP, et al. What is patient safety culture? A review of the literature. J Nurs Scholarsh 2010;42(2):156-165. DOI: 10.1111/j.1547-5069.2009.01330.x.

6. Singer SJ, Jiang W, Huang LC, et al. Surgical team member assessment of the safety of surgery practice in 38 South Carolina hospitals. Med Care Res Rev 2015;72(3):298-323. DOI: 10.1177/1077558715577479.

7. Molina G, Jiang W, Edmondson L, et al. Implementation of the surgical safety checklist in South Carolina hospitals is associated with improvement in perceived perioperative safety. J Am Coll Surg 2016;222(5):725-736.e5. DOI: 10.1016/j.jamcollsurg.2015.12.052.

8. Molina G, Singal R, Haynes AB, et al. Perception of safety of surgical practice among healthcare professionals who work in an operating room in ambulatory surgery centers in the United States: a retrospective analysis of survey data. Perioperat Care Operat Room Manage 2017;8:12-18. DOI: 10.1016/j.pcorm.2017.07.002.

9. Molina G, Berry WR, Lipsitz SR, et al. Perception of safety of surgical practice among operating room personnel from survey data is associated with all-cause 30-day postoperative death rate in South Carolina. Ann Surg 2017;266(4):658-666. DOI: 10.1097/ SLA.0000000000002378.

10. Singer SJ, Gaba DM, Geppert JJ, et al. The culture of safety: results of an organization-wide survey in 15 California hospitals. Qual Saf Health Care 2003;12(2):112-118. DOI: 10.1136/qhc.12.2.112.

11. Kho ME, Carbone JM, Lucas J, et al. Safety climate survey: reliability of results from a multicenter ICU survey. Qual Saf Health Care 2005;14(4):273-278. DOI: 10.1136/qshc.2005.014316.

12. Pronovost PJ, Weast $B$, Holzmueller CG, et al. Evaluation of the culture of safety: survey of clinicians and managers in an academic medical center. Qual Saf Health Care 2003;12(6):405-410. DOI: 10.1136/ qhc.12.6.405

13. Lee WC, Wung HY, Liao HH, et al. Hospital safety culture in Taiwan: a nationwide survey using Chinese version safety attitude questionnaire. BMC Health Serv Res 2010;10(1):234. DOI: 10.1186/14726963-10-234.

14. Taylor JA, Dominici F, Agnew J, et al. Do nurse and patient injuries share common antecedents? An analysis of associations with safety climate and working conditions. BMJ Qual Saf 2012;21(2):101-111. DOI: 10.1136/bmjqs-2011-000082.

15. Raftopoulos V, Pavlakis A. Safety climate in 5 intensive care units: a nationwide hospital survey using the Greek-cypriot version of the safety attitudes questionnaire. J Crit Care 2013;28(1):51-61. DOI: 10.1016/j.jcrc.2012.04.013.

16. Smiley K, Ofori L, Spangler C, et al. Safety culture and perioperative quality at the volta river authority hospital in Akosombo, Ghana. World J Surg 2019;43:16-23. 